\title{
Effects of Peel Extract from Gitrus reticulata and Hesperidin, A Citrus Flavonoid, on Macrophage Cell Line
}

\author{
Muthi' Ikawati1, 2*, Inna Armandari2,4, Annisa Khumaira2,5 and Yogi Ertanto ${ }^{2,3}$
}

1. Department of Pharmaceutical Chemistry, Faculty of Pharmacy, Universitas Gadjah Mada, Sekip Utara, Yogyakarta 55281, Indonesia

2. Cancer Chemoprevention Research Center, Faculty of Pharmacy, Universitas Gadjah Mada, Sekip Utara, Yogyakarta 55281, Indonesia

3. Army Medical Center, Jl. Mayjen Soetoyo, Cililitan, East Jakarta, Jakarta 13640, Indonesia

4. Department of Histology, Faculty of Medicine, Public Health, and Nursing, Universitas Gadjah Mada, Jl. Farmako, Sekip Utara, Yogyakarta 55281, Indonesia

5. Faculty of Science and Technology, Universitas Aisyiah Yogyakarta, Jl. Ring Road Barat 63, Gamping, Sleman, Yogyakarta 55292, Indonesia

\section{Info Article \\ Submitted: 03-07-2019 \\ Revised: 22-11-2019 \\ Accepted: 25-11-2019 \\ *Corresponding author \\ Muthi' Ikawati \\ Email: \\ muthi_ikawati@ugm.ac.id}

\begin{abstract}
The extract of Citrus reticulata has been studied for its biological activities, due to its citrus flavonoid content. The extract and its flavonoid compounds exhibit growth inhibition property in several cancer cell lines and in vivo models. Conversely, the extract can also induce cell proliferation and angiogenesis, and shows estrogenic effects by in vitro and in vivo. Because of the contrasting effects that depend on the concentration or dosage, the precise action of the extract and its flavonoids need to be elucidated in various cell types. The objective of this study is to evaluate the effect of Citrus reticulata peel extract (Citrus extract) and hesperidin, a citrus flavonoid, on the modulation of cell proliferation in the RAW 264.7 macrophage cell line. Cell viability under Citrus extract or hesperidin treatment was assessed by using the MTT assay. The expression of interleukin-10 (IL-10), an antiinflammatory cytokine, modulated by Citrus extract was also examined by immunostaining. Low concentrations of Citrus extract at 1 and $100 \mu \mathrm{g} / \mathrm{mL}$ were able to induce cell proliferation, although in significant, as shown by cell viability of 138 and $114 \%$, respectively. At higher concentrations of 500, 750, and $1000 \mu \mathrm{g} / \mathrm{mL}$, Gtrus extract decreased cell viability significantly by up to 64,46 , and $36 \%$, respectively. Accordingly, hesperidin at low $(3.1 \mu \mathrm{g} / \mathrm{mL}$ $-61.1 \mu \mathrm{g} / \mathrm{mL}$ ) concentration increased cell viability significantly by up to 116 $136 \%$ where as high $(152.6203 \mu \mathrm{g} / \mathrm{mL}-305.3203 \mu \mathrm{g} / \mathrm{mL})$ concentration reduced cell viability significantly by up to $10-61 \%$. The value of the $50 \%$ inhibitory concentration ( $\mathrm{IC}_{50}$ ) of Citrus extract was more than three times higher $(756 \mu \mathrm{g} / \mathrm{mL})$ than that of hesperidin $(203 \mu \mathrm{g} / \mathrm{mL}=332 \mu \mathrm{M})$. Additionally, $250 \mathrm{\mu g} / \mathrm{mL}$ of Citrus extract was able to induce IL-10 expression compared to control. These results demonstrated that Citrus extract and hesperidin exerted a biphasic effect on macrophagecells. The future development of Citrus extract as a co-chemotherapeutic, anticancer, or immunomodulatory agent should include careful consideration of its biphasic effect on each cell type.
\end{abstract}

Keywords: Citrus reticulata, hesperidin, macrophage RAW 264.7 cell, proliferation, interleukin-10 (IL-10)

\section{INTRODUCTION}

Citrus plants (family: Rutaceae) have attracted researchers' attention due to their biological activities since the early $18^{\text {th }}$ century (Manthey et al., 2001). Their phytochemical healthpromoting properties are mainly based on the anti- oxidant activities of flavonoid compounds that contribute to the cardiovascular disease and cancer prevention, anti-inflammatory, antiviral, and antimicrobial properties of citrus (Barreca et al., 2017; Benavente-Garcia et al., 1997). Citrus species contain a variety of flavonoids, namely flavonones, 
Table I. Biological activities of Citrus reticulata peel extract (Citrus extract) and hesperidin

\begin{tabular}{|c|c|c|c|c|}
\hline Material & Experimental design & Biological activity & $\begin{array}{l}\text { Concentration } \\
\text { / dosage }\end{array}$ & Reference \\
\hline \multirow[t]{8}{*}{$\begin{array}{l}\text { Citrus } \\
\text { extract }\end{array}$} & \multirow[t]{2}{*}{$\begin{array}{l}\text { In vitro assay in MCF-7 } \\
\text { breast cancer cell line }\end{array}$} & $\begin{array}{l}\text { Increases selectivity for } \\
\text { doxorubicin }\end{array}$ & & \multirow[t]{2}{*}{$\begin{array}{l}\text { (Yunas et al., } \\
\text { 2007) }\end{array}$} \\
\hline & & $\begin{array}{l}\text { Single treatment induces cell } \\
\text { proliferation }\end{array}$ & $50-400 \mu \mathrm{g} / \mathrm{mL}$ & \\
\hline & $\begin{array}{l}\text { bFGF-induced chicken } \\
\text { embryo chorio-allantoic } \\
\text { membrane }\end{array}$ & Anti-angiogenesis & $150-600 \mu g$ & $\begin{array}{l}\text { (Chrisnanto et } \\
\text { al., 2008) }\end{array}$ \\
\hline & \multirow[t]{2}{*}{$\begin{array}{l}\text { In vitro assay in } \mathrm{WiDr} \\
\text { colon cancer cell line }\end{array}$} & $\begin{array}{l}\text { Induces cell proliferation and } \\
\text { COX- } 2 \text { expression }\end{array}$ & $10-500 \mu \mathrm{g} / \mathrm{mL}$ & $\begin{array}{l}\text { (Ardiani et al., } \\
\text { 2008) }\end{array}$ \\
\hline & & Induces VEGF expression & $1.500-\mu \mathrm{g} / \mathrm{mL}$ & $\begin{array}{l}\text { (Puspita et al., } \\
\text { 2008) }\end{array}$ \\
\hline & Ovariectomized rats & $\begin{array}{l}\text { Estrogenic (modulates blood } \\
\text { cholesterol profile and increases } \\
\text { bone density) }\end{array}$ & $\begin{array}{l}500-1.000 \\
\mathrm{mg} / \mathrm{kg} \mathrm{BW}\end{array}$ & $\begin{array}{l}\text { (Adelina et al., } \\
\text { 2015) }\end{array}$ \\
\hline & \multirow[t]{2}{*}{ DMBA-induced rats } & $\begin{array}{l}\text { Inhibits breast epithelial cell } \\
\text { proliferation (reduces c-Myc } \\
\text { expression) }\end{array}$ & $\begin{array}{l}750- \\
1.500 \mathrm{mg} / \mathrm{kg} \mathrm{BW}\end{array}$ & $\begin{array}{l}\text { (Supriyati et al., } \\
\text { 2008) }\end{array}$ \\
\hline & & $\begin{array}{l}\text { Inhibits hepatic cell proliferation } \\
\text { (reduces c-Myc expression) }\end{array}$ & $\begin{array}{l}750- \\
1.500 \mathrm{mg} / \mathrm{kg} \mathrm{BW}\end{array}$ & $\begin{array}{l}\text { (Meiyanto et al., } \\
\text { 2012) }\end{array}$ \\
\hline \multirow[t]{7}{*}{ Hesperidin } & \multirow[t]{2}{*}{$\begin{array}{l}\text { In vitro assay in MCF-7 } \\
\text { breast cancer cell line }\end{array}$} & $\begin{array}{l}\text { Increases selectivity for } \\
\text { doxorubicin }\end{array}$ & & \multirow[t]{2}{*}{$\begin{array}{l}\text { (Hermawan et } \\
\text { al., 2010) }\end{array}$} \\
\hline & & $\begin{array}{l}\text { Single treatment induces cell } \\
\text { proliferation }\end{array}$ & $5-100 \mu \mathrm{M}$ & \\
\hline & $\begin{array}{l}\text { In vitro assay in T47D } \\
\text { breast cancer cell line }\end{array}$ & Cytotoxic & IC50 $200 \mu \mathrm{M}$ & $\begin{array}{l}\text { (Setiawati et al., } \\
\text { 2011) }\end{array}$ \\
\hline & \multirow{3}{*}{$\begin{array}{l}\text { In vitro assay in HeLa } \\
\text { cervical cancer cell line } \\
\text { In vitro assay in WiDr } \\
\text { colon cancer cell line }\end{array}$} & Cytotoxic & \multirow[t]{2}{*}{$\mathrm{IC}_{50} 48 \mu \mathrm{M}$} & \multirow{3}{*}{$\begin{array}{l}\text { (Kusharyanti et } \\
\text { al., 2011) } \\
\text { (Gilang et al., } \\
\text { 2012) }\end{array}$} \\
\hline & & $\begin{array}{l}\text { Increases selectivity for } \\
\text { doxorubicin }\end{array}$ & & \\
\hline & & Single treatment is not cytotoxic & $5-200 \mu \mathrm{M}$ & \\
\hline & $\begin{array}{l}\text { In vitro assay in MCF- } \\
7 / \text { HER2 breast cancer } \\
\text { cell line }\end{array}$ & $\begin{array}{l}\text { Increases selectivity for } \\
\text { doxorubicin }\end{array}$ & $\mathrm{IC}_{50} 11 \mu \mathrm{M}$ & $\begin{array}{l}\text { (Febriansah et } \\
\text { al., 2014) }\end{array}$ \\
\hline
\end{tabular}

Acronyms: bFGF, basic fibroblast growth factor; DMBA =7,12-dimethylbenz(a)anthracene

flavons, and flavonols (Benavente-García et al., 1997). Hesperidin, a flavonone glycoside, is a major flavonoid compound in Citrus reticulata (reviewed in Barreca et al., 2017). The first description of hesperidin by Lebreton in 1828 marked the beginning of researchers' vast interest in citrus flavonoids (reviewed in Manthey et al., 2001). As a fruit crop that is abundantly cultivated and consumed across the globe, citrus fruits generate a large amount of waste every year (Sharma et al., 2017). Citrus peels are one of the solid citrus waste products that need to be managed. Since 2007, the Cancer Chemoprevention Research Center, Faculty of Pharmacy, Universitas Gadjah Mada (UGM), Indonesia has been exploring the extract of citrus peels in order to reveal its chemopreventive properties and, at the same time, to increase the utility of citrus waste (reviewed in Meiyanto et al., 2012). One of the studies was focused on the ethanolic extract of Citrus reticulata, commonly known as tangerine or mandarin, which has been shown to contain flavonoids (Armandari, 2010; Meiyanto et al., 2011) (Table I). In addition, hesperidin, as one of the main compounds, has been studied (Table I).

In vitro, it induces cell proliferation and angiogenesis in MCF-7 breast or WiDr colon cancer cells at concentrations of $10-1500 \mu \mathrm{g} / \mathrm{mL}$ (Ardiani et al., 2008; Puspita et al., 2008; Yunas et al., 2007) but can suppress MCF-7 cell 
proliferation when combined with doxorubicin, a cytostatic agent (Yunas et al., 2007) (Table I). In vivo, 150-600 $\mathrm{\mu g}$ Gitrus extract shows antiangiogenic activities (Chrisnanto et al., 2008) and suppresses epithelial breast and hepatic cell proliferation in rats with chemically induced cancer at $750-1500 \mathrm{mg} / \mathrm{kg}$ BW (Supriyati et al., 2008; Meiyanto et al., 2011). In the same manner as Citrus extract, hesperidin also displays differing properties depending on its concentration and the cell type. Hesperidin $(5-200 \mu \mathrm{M})$ increases cell viability in MCF-7 and WiDr cells but decreases cell viability more effectively in combination with an anticancer agent than the anticancer agent alone (Gilang et al., 2012; Hermawan et al., 2010). In the other cancer cell lines, T47D breast, HeLa cervix, and MCF-7 with HER2 over-expression (MCF-7 / HER2), hesperidin exhibits an IC50 value varying

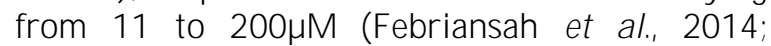
Kusharyanti et al., 2011; Setiawati et al., 2011). The effect of Citrus extract on MCF-7/ HER2 is contrary to the estrogenic effect seen in ovariectomized mice (Adelina et al., 2015). In summary, Citrus extract and hesperidin may act differently depending on the concentration and the cell type. The dual or biphasic effect of these compounds on cell proliferation will influence whether the expected effect on cells is antiproliferative or proliferative. Therefore, the precise action of Citrus extract and citrus flavonoids need to be elucidated in various cell types. Besides the exploration of its anticancer potency, citrus and citrus flavonoids have also been studied for their anti-inflammatory activities (Manthey et al., 2001). Our group's work has been focused mainly on cancer cells, not on normal or inflammation-related cells (Table I). To our knowledge, no study has yet addressed the dual effect of citrus extract or citrus flavonoids on cell proliferation. Hence, an investigation of Citrus extract and citrus flavonoids on normal or inflammatory-related cells, i.e., macrophages, is important, especially considering the probability of their contradictory concentration-dependent effect. In this study, we evaluate the effect of ethanolic extract from Citrus reticulata peel (Citrus extract) and hesperidin at various concentrations on the modulation of cell proliferation in the RAW 264.7 macrophage cell line. We reveal that both Citrus extract and hesperidin show a biphasic effect on RAW 264.7 macrophage cell viability. Additionally, Citrus extract at a moderate tested concentration can induce the expression of interleukin-10 (IL-10), an anti-inflammatory cytokine.

\section{MATERIAL AND METHODS \\ Preparation of Citrus extract}

Citrus reticulata fruits were obtained from Kalisoro, Tawangmangu, Central Java, Indonesia in September and were identified in the Laboratory of Pharmacognosy, Department of Pharmaceutical Biology, Faculty of Pharmacy, Universitas Gadjah Mada (UGM). Healthy, green, mature but unripe fruits were washed, and the peels were collected and air dried without direct sunlight. Dried peels were powdered and macerated in 70\% ethanol (Merck, Darmstadt, Germany) (10L for $1 \mathrm{~kg}$ powder) for 5 days as previously described (Adelina et al., 2008). The ethanolic fraction was separated and evaporated in a rotary vacuum evaporator until a brown viscous extract was obtained (yield was 3.21\% (b/b)) (Armandari, 2010). The obtained extract was then identified by thin layer chromatography to detect flavonoid components as previously described (Meiyanto et al., 2011). After citrobroric treatments, positive spots indicating flavonoids were developed under 245 and 366nm UV lights (Armandari, 2010). This extract is heretofore referred to as "Gitrus extract."

\section{Preparation of tested materials}

Citrus extract was first diluted in dimethyl sulfoxide (DMSO) $(99.5 \%$ pro GC, Sigma Aldrich, Germany) as a stock solution of $50 \mathrm{mg} / \mathrm{mL}$ and then serially diluted in culture medium to reach the designated concentrations (1; $5 ; 10 ; 25 ; 50 ; 75 ; 100 ; 250 ; 500 ; 750$; and $1,000 \mu \mathrm{g} / \mathrm{mL}$ ) with a maximum final DMSO concentration of $2 \%(\mathrm{v} / \mathrm{v})$. The same preparation procedure was also carried out for hesperidin (Sigma Aldrich, Germany), a citrus flavonoid, as a comparison $(1,5,10,25,50,100,250$, and $500 \mu \mathrm{M}$.

\section{Cell culture}

The murine monocyte macrophage RAW 264.7 cell line was a gift from Prof. Tatsuo Takeya (Nara Institute of Science and Technology, Japan). Cells were cultured in Minimum Essential Media (Gibco, USA) supplemented with $10 \% \quad(\mathrm{v} / \mathrm{v})$ Newborn Calf Serum (NBCS) (Gibco, USA) and 2\% (v/v) penicillin-streptomycin (Gibco, USA) in a $37^{\circ} \mathrm{C}, 5 \% \mathrm{CO}_{2}$ incubator and grown to confluence in $75 \mathrm{~cm}^{3}$ tissue culture flasks. After they reached $80 \%$ confluence, cells were scraped and used for experiments. 


\section{Cell viability assay}

Cells $\left(5 \times 10^{3}\right.$ cells/ well) were plated in 96well plates and cultured in a complete medium for $48 \mathrm{~h}$. The medium was then replaced with a medium containing various concentrations of Citrus extract or hesperidin and incubated for $24 \mathrm{~h}$. Cell viability was assessed by the MTT method as previously described (Ikawati et al., 2018) and carried out in at least triplicate for each experiment. Briefly, the absorbance at $595 \mathrm{~nm}$ of diluted formazan after addition of $0.5 \mathrm{mg} / \mathrm{mL} 3$-(4,5-dimethylthiazolyl-2)2,5-diphenyltetrazolium bromide (MTT) (Sigma Aldrich, Germany) in phosphate-buffered saline (PBS) followed by stopper solutions (10\% SDS (Merck, Germany) in 0.1NHCl (Merck, Germany)) were measured in a microplate reader (Bio-Rad, Japan). The detailed step-by-step protocol is described in Armandari (2010). Untreated cells served as a control, while wells without cells served as a blank. The percent cell viability and the IC50 value were calculated as (absorbance of treated cells - absorbance of blank)/(absorbance of control - absorbance of blank) $\times 100 \%$ and by linear regression analysis as follows: cell viability $(\%, \mathrm{y}$ axis) vs log concentration $(\mu \mathrm{g} / \mathrm{mL}$ or $\mu \mathrm{M}, \mathrm{x}$ axis) (Ikawati et al., 2018), including all tested dosage of the concentration series). Data are presented as the mean of two or three measurements per condition per experiment.

\section{Immunostaining}

Immunocytochemistry with an anti-IL-10 mouse monoclonal antibody (Dako) was carried out by the avidin-biotin complex method as previously described (Ardiani et al., 2008). Cells (1 $\mathrm{x} 10^{5}$ cells/ well) were plated on coverslips in a 24well plate until they reached $80 \%$ confluence. Cells were then incubated with Citrus extract at the designated concentrations for $15 \mathrm{~h}$. After removal of the medium, cells were washed with cold PBS, and then were fixed in cold methanol for $10 \mathrm{~min}$ at $-20^{\circ} \mathrm{C}$. The endogenous peroxidase activity was blocked with hydrogen peroxide, and nonspecific sites were blocked with normal goat serum (Novocastra), for $10 \mathrm{~min}$ each at room temperature, followed by incubation in the primary antibody, anti-IL-10 (1:50), overnight at $4^{\circ} \mathrm{C}$. After washing with PBS, cells were incubated in IgG biotinylated universal secondary antibody (Novocastra) for $10 \mathrm{~min}$. Following washing, cells were incubated with streptavidin-peroxidase complex reagent (Novocastra) for $10 \mathrm{~min}$ and then incubated with 3,3-diaminobenzinidine (DAB) substrate solution (Novocastra) for 2-10min to visualize the bound biotin. Cover slips were washed in distilled water and counterstained with Mayer's hematoxylin (Dako) for 1-3min. Cells were dehydrated in ethanol, cleared in xylene, and cover slips were mounted with a mounting medium. Protein expression was observed qualitatively with a light microscope (Olympus). A stained cover slip without primary antibodies served as a control.

\section{Statistical analysis}

Data are presented as mean \pm standard deviation (SD) and were analyzed for significance using the Student's t-test. Values of $p<0.05$ were considered to indicate significance.

\section{RESULTS AND DISCUSSION}

\section{Higher, but not lower, concentrations of Citrus} extract decrease RAW 264.7 cell viability

To examine the inhibition or induction of cell proliferation, RAW 264.7 cells were treated with a series of concentrations of Citrus extract, in the range from 1 to $1,000 \mu \mathrm{g} / \mathrm{mL}$, for $24 \mathrm{~h}$. As expected, lower concentrations of Citrus extract did not affect cell morphology. The cell morphology at lower concentrations (i.e., $10 \mu \mathrm{g} / \mathrm{mL}$ and $50 \mu \mathrm{g} / \mathrm{mL}$ ) appeared the same as that of control cells (Figure 1A). Moreover, the cell density increased after treatment with $50 \mu \mathrm{g} / \mathrm{mL}$ extract. In contrast, at higher concentrations, starting at $500 \mu \mathrm{g} / \mathrm{mL}$, more cells appeared rounder and less flattened out in the well. These morphological observations imply a biphasic effect of Citrus extract.

After $24 \mathrm{~h}$ of incubation with Citrus extract, cell viability was assayed by the MTT method. The higher concentrations of Citrus extract $(500 \mathrm{\mu g} / \mathrm{mL}$, $750 \mu \mathrm{g} / \mathrm{mL}$, and $1000 \mu \mathrm{g} / \mathrm{mL}$ ) were able to decrease cell viability significantly $(64 \%, 46 \%$, and $36 \%$, respectively, compared with $100 \%$ in the control without Citrus extract treatment) (Figure 1B). The cell viability in the presence of $250 \mu \mathrm{g} / \mathrm{mL}$ Citrus extract was $96 \%$, while lower concentrations increased the cell viability, though not significantly, ranging from $108 \%$ to $138 \%$. The highest cell viability was given by the lowest tested concentration, $1 \mu \mathrm{g} / \mathrm{mL}$. Thus, Citrus extract demonstrated a biphasic effect on RAW 264.6 macrophage cell proliferation.

\section{Biphasic effects of hesperidin on RAW 264.7 cell viability}

Hesperidin is one of the citrus flavonoids, a major compound in Citrus extract or citrus in general. Therefore, a similar cell viability assay was also carried out for hesperidin to determine 
A

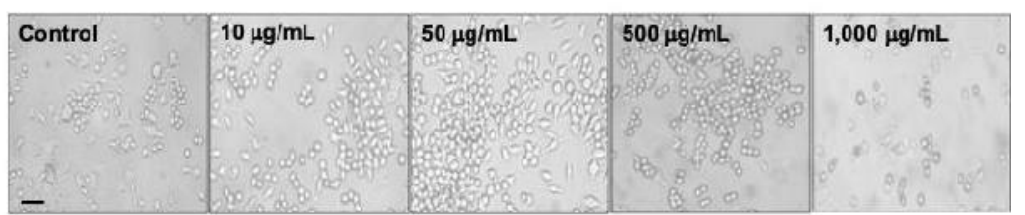

B

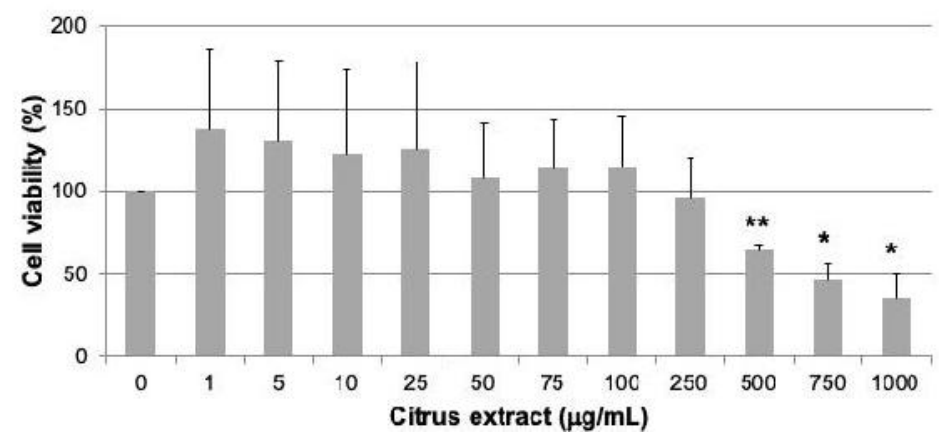

Figure 1. Effects of Citrus extract on cell viability in RAW 264.7 macrophage cells. Cells were treated with a concentration series of Citrus extract, incubated for $24 \mathrm{~h}$, and then assayed by MTTassay in pentaplicate. A. Cell morphology and density were observed under a microscope, and representative pictures are presented. Scale bars $=100 \mu \mathrm{m}$. B. The graph of Citrus extract treatment demonstrated a biphasic effect on cell viability. The experiments were carried out twice, and the graph represents means $\pm=S D(n=2)$. Statistical significance was determined by means of the Student's t-test. Asterisks indicate a significant decrease $(* ; p<0.05 . * * ;<0.01)$ in cell viability compared with the control.

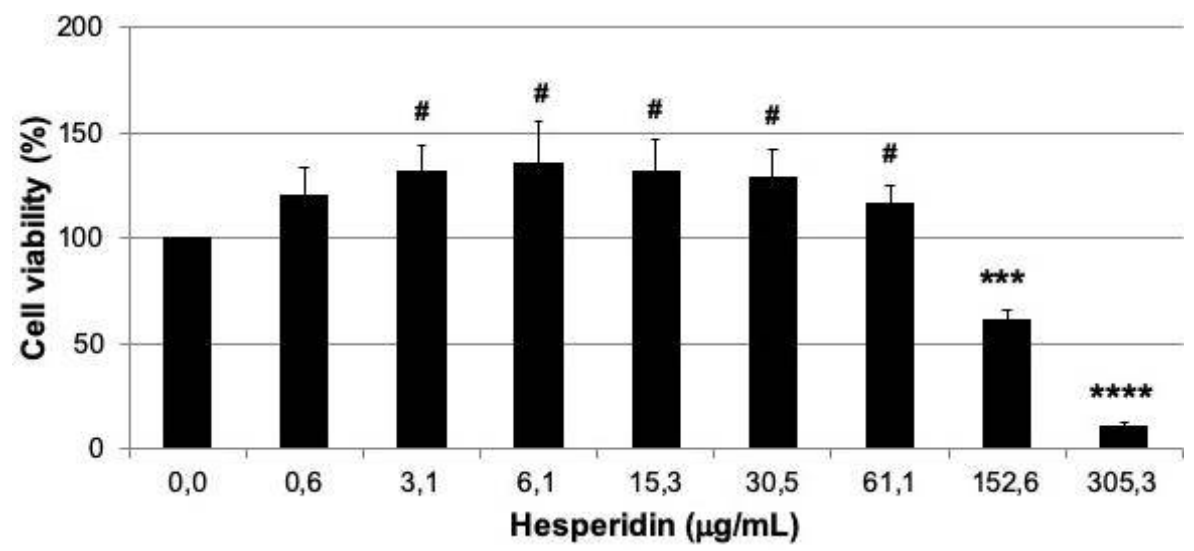

Figure 2. Effects of hesperidin on cell viability in RAW 264.7 macrophage cells. Cells were treated with a concentration series of hesperidin, incubated for $24 \mathrm{~h}$, and then assayed by MTT assay in triplicate. The graph of hesperidin treatment demonstrated a biphasic effect on cell viability. The experiments were carried out three times, and the graph represents means $\pm S D(n=3)$. Statistical significance was determined by means of the Student's t-test. Hash tags indicate significant increase $(\# ; \mathrm{p}<0.05)$ on cell viability compared with the control. Asterisks indicate a significant decrease (***; $<<0.001 * * * * ; p<0.0001)$ in cell viability compared with the control.

whether this compound would exert a similar biphasic effect to the extract. A series of concentrations varying from $1 \mu \mathrm{M}$ to $500 \mu \mathrm{M}$ (equal to $0.6 \mu \mathrm{g} / \mathrm{mL}-305.3 \mu \mathrm{g} / \mathrm{mL}$ ) was used (Figure 2). The lowest tested concentration did not significantly affect cell viability. However, at 5-100 $\mu \mathrm{M}$, hesperidin increased cell viability significantly $(116 \%-136 \%$ compared with $100 \%$ in the control without hesperidin treatment). At higher concentrations, hesperidin decreased cell 
viability by as much as $61 \%$ and $10 \%$ at $250 \mu$ Mand $500 \mu \mathrm{M}$, respectively. These data confirmed the biphasic effect of Citrus extract on cell proliferation, and that effect was likely caused by its citrus flavonoid content.

\section{Citrus extract has a lower $\mathrm{IC}_{50}$ value compared with hesperidin in RAW 264.7 cells}

IC50 values were calculated based on linear regression equations derived from the graph of concentration versus cell viability (Figure 3 ). The $\mathrm{IC}_{50}$ of Citrus extract and hesperidin was $756 \mathrm{~g} / \mathrm{mL}$ and $203 \mu \mathrm{g} / \mathrm{mL}(332 \mu \mathrm{M})$, respectively, as expected ranging at the high tested concentration. The $\mathrm{IC}_{50}$ of Citrus extract was 3.7 times higher than that of hesperidin. This is plausible because Citrus extract may contain other compounds. Nevertheless, at the given $\mathrm{IC}_{50}$, studies on the utilization of Citrus extract rather than hesperidin may yield additional advantages, especially if the accessibility of a pure compound is limited.
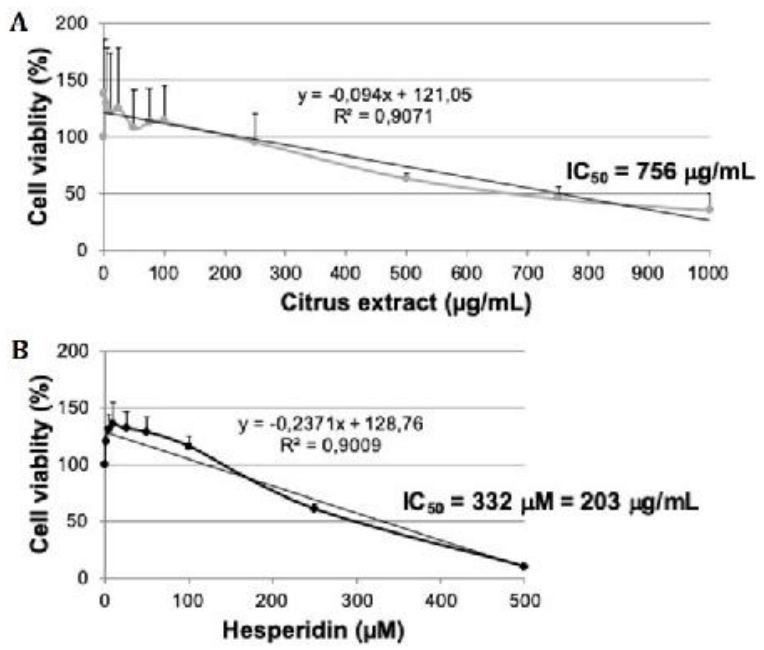

Figure 3. The $\mathrm{IC}_{50}$ value of Citrus extract or hesperidin in RAW264.7 macrophage cells. Cells were treated with a concentration series of Citrus extract (A) or hesperidin (B) for $24 \mathrm{~h}$ and then assayed by the MTT method. Graphs of concentration versus percentage cell viability are presented as indicated. Points in A and B are presented as the mean of two or three experiments, respectively. The $\mathrm{IC}_{50}$ value was calculated by linear regression analysis as stated on each graph.

\section{Citrus extract can induce IL-10 expression}

Treatment with $250 \mu \mathrm{g} / \mathrm{mL}$ Citrus extract induced expression of IL-10, an anti-inflammatory cytokine, indicated by a brownish color in the cytoplasmic area compared with control IgG (Figure 4, rightmost panel versus leftmost panel). However, at a concentration of $25 \mu \mathrm{g} / \mathrm{mL}$, Citrus extract did not affect IL-10 expression and appeared similar to cells without Citrus extract treatment $(0 \mu \mathrm{g} / \mathrm{mL})$. Higher concentrations should be tested further to confirm whether the modulation of IL-10 expression caused by Citrus extract is also ensuing the biphasic trend.

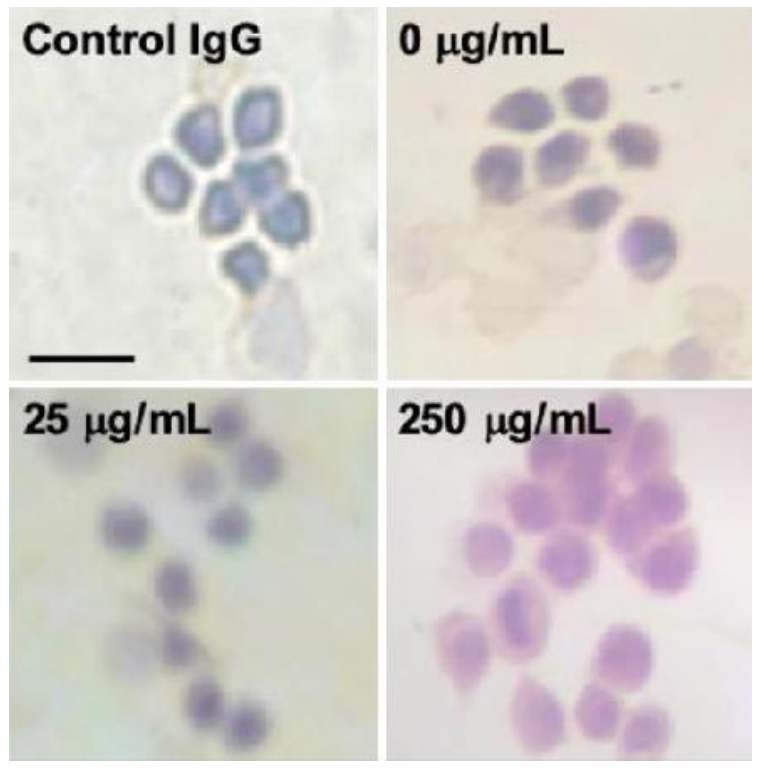

Figure 4. Effects of Citrus extract treatment on the expression of interleukin-10 (IL-10). Cells were incubated with Citrus extract at the indicated concentrations for $15 \mathrm{~h}$. Cells were immunostained for IL-10 (brown) and counterstained with Mayer's hematoxylin to visualize nuclei (blue). Staining without primary antibody served as a control (leftmost panel). Scale bar $=50 \mu \mathrm{m}$.

Our findings exhibit that the ethanolic extract of Citrus reticulata (Citrus extract) and hesperidin, a citrus flavonoid, display a biphasic effect on the proliferation of a monocyte macrophage cell line, indicated by the cell viability parameter (Figure 1B and 2). More importantly, the concentration of Citrus extract required to increase RAW 26.7 cell viability varied from $1 \mu \mathrm{g} / \mathrm{mL}$ to $250 \mu \mathrm{g} / \mathrm{mL}$ (Figure $1 \mathrm{~B}$ ) compared with $10-1,500 \mu \mathrm{g} / \mathrm{mL}$ in cancer cell lines ( Yunas et al., 2007; Ardiani et al., 2008; Puspita et al., 2008). Meanwhile, hesperidin at low concentrations $(5-100 \mu M)$ can increase cell viability (Figure 2), similarly in cancer cell lines (5-100 or $200 \mu \mathrm{M})$ (Hermawan et al., 2010; Gilang et al., 2012). The $\mathrm{IC}_{50}$ value of hesperidin in the monocyte 
macrophage cell line is 1.7-30 times higher than in cancer cell lines (Figure 3B) (Kusharyanti et al., 2011; Setiawati et al., 2011; Febriansah et al., 2014). Taken together, the use of Citrus extract or hesperidin should carefully deliberate the concentration or dosage and the cell type.

Macrophages express interleukin-10 (IL-10) and usually triggered by inflammatory stimuli (Chung et al., 2007). Since citrus flavonoids has been studied extensively for their antiinflammatory activity (Manthey et al., 2001), it is plausible to observe IL-10 expression under Citrus extract or hesperidin treatments. Due to our limitations (Figure 4). At 250 $\mu \mathrm{g} / \mathrm{mL}$, Gitrus extract can induce IL-10 expression, but not at lower concentrations. In the future study, higher concentrations of Citrus extract should be tested to confirm whether the modulation of IL-10 expression caused by Citrus extract also follows the pattern of a dual effect. Furthermore, the expression of cyclooxygenase-2 (COX-2), one of the key enzymes in inflammation, was also tested. However, there was no COX-2 detected (data not shown). An inflammatory stimulus such as lipopolysaccharide (LPS) should be administered to the cells, similarly to the ones that have been reported previously (Kang et al., 2011; Sakata et al., 2003).

At lower concentrations, Citrus extract was able to maintain cell viability independently of the expression of the anti-inflammatory cytokine IL10. Meanwhile, hesperidin at a lower concentration was able to promote cell proliferation. Therefore, a low concentration of Citrus extract and hesperidin is possibly useful for treating inflammatory diseases. On the other hand, application of a low concentration of Citrus extract or hesperidin should be avoided for cancer cells because it induces cell proliferation as previously reported in a colon cancer cell line by Ardiani et al. (2008). Alternatively, at higher concentrations, Citrus extract or hesperidin is beneficial to cancer cells due to their cytotoxic effects. Recently, genistein, another flavonoid found in soybean, a widely known potential chemopreventive agent, has been reported to demonstrate a biphasic mechanism on CHO-K1 cells: at low concentrations, it induces senescence and apoptosis in combination with estrogen, and at high concentrations, it modulates the cell cycle (Jenie et al., 2019). Hence, an investigation of the dose-dependent mechanism of Citrus extract and hesperidin should be carried out further.

\section{CONCLUSION}

Citrus extract and hesperidin exerted a biphasic effect on a macrophage cell line. The future development of Citrus extract as a co-chemotherapeutic, anticancer, or immunemodulatory agent should include careful consideration of its biphasic effect on each cell type.

\section{ACKNOWLEDGMENT}

This study was partly funded by "Hibah Penelitian Berkualitas Prima" (Prime Quality Research Grant) Faculty of Pharmacy UGM 2009 (granted to MI). The authors wish to state their contributions as follow: IA performed experiments for the Citrus extract; AK and YE performed cell viability assays for hesperidin; MI and IA wrote the manuscript and prepared the figures; MI oversaw all aspects of the study. All authors have read and approved the manuscript.

\section{REFERENCES}

Adelina R., Supriyati MD., Nawangsari DA., Jenie RI., and Meiyanto E., 2008, Citrus reticulata's peels modulate blood cholesterol profile and increased bone density of ovariectomized rats, Indones. J. Biotechnol., 13(2): 10921097. DOI: $10.22146 /$ ijbiotech.7800

Ardiani M., Puspita N., Goenadi FA., Septisetyani EP., and Meiyanto E., 2008, The ethanolic extract of Citrus reticulata's peels induces proliferation and COX-2 expression in WiDr colon cancer cells, in Transformation of Science and Technology in Pharmaceutical Professional Practice: Proceeding of the XVI Indonesian Pharmacy Association Scientific Congress 2008, edited by Pudjono, Indonesian Pharmacy Association, Yogyakarta, Indonesia. ISBN: 978-97995108-6-0. pp. 193-198 (in Indonesian)

Armandari I., 2010, Immunomodulatory activities of ethanolic extract from Citrus reticulata's peels through macrophage proliferation and expression of interleukin-10 in macrophage RAW 264.7 cells, Undergraduate Thesis, Faculty of Pharmacy Universitas Gadjah Mada Yogyakarta, Indonesia (in Indonesian)

Barreca D., Gattuso G., Bellocco E., Calderaro A., Trombetta D., et al., 2017, Flavanones: Citrus phytochemical with health-promoting properties, BioFactors, 43(4): 495-506. DOI: 10.1002/ biof.1363 
Benavente-Garcia O., Castillo J., Marin FR., Ortuni A., and Del Rio JA., 1997, Uses and properties of Citrus flavonoids, J. Agric. Food Chem., 45(2): 4505-4515

Chrisnanto E., Adelina R., Putri DPP., Sahid MNA., Setyaningtias D., et al., 2008, Antiangiogenic effect of ethanol extract of Citrus reticulata peel in the Chorio Allantoic Membrane (CAM) induced by bFGF, in The International Symposium on Molecular Targeted Therapy: Proceeding, edited by Pudjono et al, Faculty of Pharmacy Universitas Gadjah Mada, Yogyakarta, Indonesia. ISBN: 978-97995107-6-1.pp. 57-66

Chung EY., Liu J., Homma Y., Zhang Y., Brendolan A., et al., 2007, Interleukin-10 expression in macrophage during phagocytosis of apoptotic cells is mediated by the TALE homeoproteins Pbx-1 and Prep-1, Immunity, 27(6): 952-964. DOI: 10.1016/j.immuni.2007.11.014

Febriansyah R., Putri, DPP., Sarmoko, Nurulita NA., Meiyanto E., and Nugroho AE., 2014, Hesperidin as a preventive resistance agent in MCF-7 breast cancer cells line resistance to doxorubicin, Asian Pac. J. Trop. Biomed., 4(3): 228-233. DOI: 10.1016/ S22211691(14)60236-7

Gilang Y., Hermawan A., Fitriasari A., and Jenie RI., 2012, Hesperidin increases cytotoxic effect of 5-fluorouracil on WiDr cells, Indonesian J. Can. Chemoprev., 2012, 3(2): 404-409. DOI: 10.14499/indonesianjcanchemoprev3iss2p p404-409

Hermawan A., Meiyanto E., and Susidarti RA, 2010, Hesperidin increase cytotoxic effect of doxorubicin in MCF-7 cells, Indonesian J. Pharm., 21(1): 8-17. DOI: 10.14499/ indonesianjpharm0iss0pp8-17 (in Indonesian with English abstract)

Ikawati M., Purwanto H., Imaniyyati NN., Sagiyo ML., Yohanes S., Set al., 2018, Cytotoxicity of Tetrahydropentagamavunon-0 (THPGV-0) and Tetrahydropentagamavunon-1 (THPGV-1) on several cancer cell lines, Indonesian J. Pharm., 29(4): 179-187. DOI: 10.14499/ indonesianjpharm29iss4pp179

Jenie RI.,Amalina ND., Ilmawati GPN., Utomo RY., Ikawati M., et al., 2019, Cell cycle modulation of CHO-K1 cells under genistein treatment correlates with cells cenescence, cpoptosis and ROS level but in a dose-dependent manner, Adv. Pharm. Bull., 9(3): 453-461. DOI: $10.15171 /$ apb.2019.054
Kang SR., Park KI., Park HS., Lee DH., Kim JA., et al., 2011, Anti-inflammatory effect of flavonoids isolated from Korea Citrus aurantium L. on lipopolysaccharide-induced mouse macrophage RAW 264.7 cells by blocking of nuclear factor-kappa B (NF-kB) and mitogen-activated protein kinase (MAPK) signalling pathway, Food Chem., 129(4): 2721-1728.

DOI: 10.1016/j.foodchem.2011.06.039

Kusharyanti I., Larasati, Susidarti RA., and Meiyanto E, 2011, Hesperidin increases cytotoxic activity of doxorubicin on Hela cell line through cell cycle modulation and apoptosis induction, Indonesian J. Can. Chemoprev., 2(2): 267-273. DOI: 10.14499/indonesianjcanchemoprev2iss2p p267-273

Manthey JA., Guthrie N., and Grohmann K., 2001, Biological properties of citru flavonoids pertaining to cancer and inflammation, Curr. Med. Chem., 8(2): 135-153

Meiyanto E., Hermawan A., and Anindyajati, 2012, Natural products for cancer-targeted therapy: citrus flavonoids as potent chemopreventive agents, Asian Pac.J. Cancer Prev., 13(2): 427-436. DOI: 10.7314/ APJCP.2012.13.2.427

Meiyanto E., Wardani DAK., Nugroho PA., Darma AP., and Ikawati M., 2011, Chemopreventive potency of ethanolic extract of Citrus reticulata on DMBA-induced rat liver, Pharmacon, 12: 9-13. DOI: 10.23917/ pharmacon.v12i1.42 (in Indonesian with English abstract)

Puspita N., Ardiani, M., Fina AG., Septisetyani EP., and Meiyanto E., 2008, The ethanolic extract of mandarin citrus (Citrus reticulata)'s peels increases the expression of angiogenic factor VEGF in WiDr colon cancer cells, in Transformation of Science and Technology in Pharmaceutical Professional Practice: Proceeding of the XVI Indonesian Pharmacy Association Scientific Congress 2008, edited by Pudjono, Indonesian Pharmacy Association, Yogyakarta, Indonesia. ISBN: 978-979-95108-6-0. pp. 50 - 54 (in Indonesian)

Sakata K., Hirose Y., Qiao Z., Tanaka T., and Mori H., 2005, Inhibition of inducible isoforms of cyclooxygenase and nitric oxide synthase by flavonoid hesperidin in mouse macrophage cell line, Cancer Lett., 199(2): 139-145. DOI: 10.1016/ S0304-3835(03)00386-0 
Setiawati A., Susidarti R.A., and Meiyanto E., 2011, Increasing cytotoxic effect of doxorubicin by hesperidin on T47D cancer cell, Bionatura Journal of Life and Physical Sciences, 13(2): 85-92 (in Indonesian with English abstract)

Sharma K., Mahato N, Cho MH., and Lee RY., 2017, Converting citrus waste into value-added products: economic and environmentally friendly approaches, Nutrition, 34(2017): 29-46. DOI: $10.1016 /$ j.nut.2016.09.006

Supriyanti MD., Adelina R., Nawangsari DA., Ikawati M., and Meiyanto E., 2008, Modulation of c-Myc expression on epithelial cells of rat mammae by ethanolic extract of Citrus reticulata's peel, in Transformation of Science and Technology in Pharmaceutical Professional Practice: Proceeding of the XVI Indonesian Pharmacy Association Scientific Congress 2008, edited by Pudjono, Indonesian Pharmacy Association, Yogyakarta, Indonesia. ISBN: 978-97995108-6-0. pp. 70-74 (in Indonesian)

Yunas SR., Latifah N., Rokhman MR., Fitriasari A., and Meiyanto, E, 2007, Ethanolic extract of mandarin orange (Citrus reticulata) peels to increase the sensitivity of MCF-7 breast cancer cell to doxorubicin, Pharmacon, 8(2): 64-69 (in Indonesian with English abstract) 